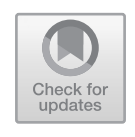

\title{
Operation Barbarossa and the Holocaust by Bullets-Bottom-Up Forces
}

Having examined the top-down forces the SS leadership exerted on the extermination campaign, this chapter explores the bottom-up forces generated by those in the killing field. What becomes apparent is when managers and their functionaries work within an organizational process, they typically move toward "improving" an initially rudimentary system, much like Milgram and Williams did during the Obedience studies. With increasing experience over time-past history-some innovators add efficiencies and eliminate inefficiencies, which helps advance the organizational system in the desired direction. As we shall see, during the Nazi regime's pursuit of the Holocaust by bullets, many of these kinds of innovations focused on making the act of killing with guns both more efficient and sufficiently palatable for the German executioners. In this, I would argue, the Holocaust by bullets resembles Milgram's pilot studies where participants invented their own strain resolving coping mechanisms from the bottom-up, for example, avoidance behaviors where they purposefully looked away from the learner. These kinds of bottom-up innovations made what Milgram wanted psychologically easier (less stressful) for the participants to engage in. Likewise, on the Eastern front the easier the participation in harm doing became psychologically, the greater the proportion of ordinary Germans willing to partake in the infliction of harm. And the longer these Germans continued to participate, the greater the devastation. As this and the remaining chapters demonstrate, the more attention one pays to the strain resolving power

(C) The Author(s) 2019

N. Russell, Understanding Willing Participants, Volume 2, https://doi.org/10.1007/978-3-319-97999-1_5 
of the means of inflicting harm, the clearer the internal logic behind the Nazis' machinery of destruction becomes.

As I showed in the previous chapter, although Himmler and his commanders did all they could to ensure their men did what they wanted, mere words and orders could not eliminate the intense perceptual experience of shooting unarmed civilians at close range. As this chapter will show, squad commanders and executioners alike soon realized that if they wanted to avoid mental breakdowns, they would have to find their own more effective ways of relieving themselves of the "burdening of the soul." This is the kind of situation where, as Bauman argues, from the bottom-up, "bureaucracy picks up where visionaries stop."

Although "Every...squad had its preferred methods," 2 after "lessons learned,"3 certain innovators in the field discovered a series of less stressful and more efficient ways to shoot civilians. And after regular meetings "to debate the most efficient methods" 4 and "frequent information exchanges," 5 the most effective of these ideas spread to other squads. What follows is a very general big-picture overview of the transition from the earliest (rudimentary) inefficient and strain inducing shooting techniques to the emergence of the most efficient and popular strain resolving "one best way" of shooting civilians en masse. To gain a basic overview of what took place, we must briefly return to the start of Operation Barbarossa and the first mass shooting undertaken by Einsatzkommando Tilsit.

\section{The First Executions}

Einsatzkommando Tilsit's first execution in Gargždai on 24 June differed from the early Polish executions in important ways. First, before the mass shooting, Tilsit's men searched for an existing burial siteperhaps a hill-shaped land formation, ravine, or in their case, a tank trap. Second, victims were instructed to stand on the grave's edge and were then shot, so that most would fall into the pit. As a result, their bodies quickly and conveniently disappeared from the shooters' sight. ${ }^{6}$ Because the shooters did not have to dig the grave and then drag all the bodies into it, they avoided significant physical labor (efficiency) and did not have to touch the bodies or see the unsettling wounds they had just inflicted on defenseless civilians. ${ }^{7}$ Finally, this more efficient technique allowed the men to more effectively separate cause (pulling the trigger) from effect (killing). After the shootings, the executioners quickly filled in the graves and moved on. To save themselves the effort of having to 
search for a burial site, an even more efficient approach was to force the victims or locals requisitioned from the community to dig graves. ${ }^{8}$ For a photograph showing Lithuanian Jews forced by Germans to dig a grave pit in 1941, see https://dachaujacket.omeka.net/exhibits/show/photos/item/4602. Clearly, these new innovations first emerged at some point between the first executions of civilians during the Polish invasion and the start of Operation Barbarossa. ${ }^{9}$

After the men from Einsatzkommando Tilsit had secured a burial site, the condemned were instructed to walk toward the tank trap. On arrival.

A group of ten men was forced to take up position at the edge of the pit with their faces turned toward the execution commando. The twenty-man strong firing party stood at a distance of twenty meters from the pit's edge. Two marksmen aimed their rifles at one victim, an SS officer gave the order to shoot. After each round a new group was driven to the edge of the pit and forced to push into it any corpses that had not fallen in on their own. [italics added] ${ }^{10}$

Despite all these innovations, perhaps having to look at the facial expressions of people in their last moments resulted in some executioners showing signs of "burdening of the soul" and succumbing "to feelings of nausea and nervous tension...."ll

One of the earliest and more popular strain resolving techniques for dealing with this stress was to consume alcohol.

In Gargždai, Kretinga and Palanga, coveted schnapps rations were distributed [to the Tilsit executioners] following each Judenaktion, [...] Killing orders issued in July 1941 instructed the SS and Police commanders to ensure that members of the execution commandos came to no harm. Within the framework of seelische Betreunng (pastoral care), social get-togethers in the evenings as well as excursions...took place in order to wipe out the impressions of the day. ${ }^{12}$

As Hilberg observes, most of the shooting squad members "were drunk most of the time-only the 'idealists' refrained from the use of alcohol." 13 Alcohol was rationed by commanding officers and became a central part of the extermination process for some squads. For example, because the mass shootings were associated with a decline in squad morale, Alfred Filbert of Einsatzkommando 9 thought it wise to issue his men with increasing rations of vodka. ${ }^{14}$ 
Elsewhere, Einsatzgruppe $\mathrm{C}$ relied on a similar yet more proximate shooting technique to Tilsit during its first executions. As one shooter noted, "In Rovno I had to participate in the first shooting... Each member of the firing-squad had to shoot one person. We were instructed to aim at the head from a distance of about ten metres." 15 After firing at about five people, this squad member stopped due to "nervous strain...." 16 To alleviate this strain, the method of shooting was changed: Several shooters were tasked with firing at each victim. On 12 July 1941, Einsatzkommando member Felix Landau noted in his diary a problem with the multiple-shooter-per-victim technique. "Six of us had to shoot them. The job was assigned thus: three at the heart, three at the head. I took the heart. The shots were fired and the brains whizzed through the air. Two in the head is too much. They almost tear it off."17 Although this shooting technique produced a disturbing visual spectacle, many commanders, like Ohlendorf from Einsatzgruppe D, initially preferred it because it helped to "avoid any individual having to take direct, personal responsibility." 18

The general passivity with which many, though certainly not all, Jews went to their deaths may also have aided in reducing the perceptual intensity of what would otherwise have been for their executioners a much more emotionally disturbing task. A Wehrmacht cadet officer based in Ukraine wrote in August 1941.

What struck me particularly was the calmness and discipline of these [Jewish] people. [...] The marksmen were members of the SS. On the orders of a superior they fired shots at the heads of these people with their carbines. [...] Sometimes the tops of their skulls flew up into the air. [...] The people who were to be shot walked towards this grave as though they were taking part in a procession. [...] They went composed and quietly to their deaths. I saw only two women weep the whole time I observed such executions. I found it simply inexplicable. ${ }^{19}$

Was this cadet trying to "blame the victims" for not resisting? ${ }^{20}$ Other witnesses, like Alfred Metzner, suggested that some Jews even went to the trouble of reducing the stressful nature of the executioners' task by going to their deaths in an orderly-some might say considerate-manner. "It was amazing... how the Jews stepped into the graves, with only mutual condolences in order to strengthen their spirits and in order to ease the work of the execution commandos." 21 Why did the victims 
behave this way? Perhaps on realizing that escape was near impossible, facilitating a carefully aimed and immediately lethal (painless?) shot was surely preferable to a slower death associated with resisting. ${ }^{22}$ Complying with, and thereby accommodating, an irrational goal like mass extermination made some rational sense.

"Gypsies" (Roma), however, who as Untermenschen were also targeted during the Soviet campaign, frequently caused greater difficulties for German shooting squads. As Lieutenant Colonel Walther stated,

Shooting the Jews is easier than shooting the gypsies [sic]. I have to admit that the Jews are very composed as they go to their death-they stand very calmly — while the gypsies [sic] wail and scream and move about constantly when they are already standing at the execution site. ${ }^{23}$

But it was the mentally ill who put up the greatest resistance. After Stahlecker's destructive Einsatzgruppe A shot 748 mentally ill Lithuanians in October 1941 because they were apparently a "danger" to security, the Wehrmacht asked them to repeat the exercise at a similar institution. Stahlecker refused to repeat the exercise, arguing to Himmler that if the Wehrmacht deemed such dirty work so necessary then they should do it themselves. ${ }^{24}$ What Stahlecker and his men had discovered was that mentally institutionalized people typically refused to follow the instructions of those who intended to kill them and, as a result, they frequently became hysterical. The ensuing panic made the targets difficult to kill with one shot (thus greatly heightening and prolonging the perpetrators' stress). Even Jäger's prolific Einsatzkommando 3 had, by 1 February 1942, only managed to shoot 653 mentally ill patients out of a total of 138,272 victims (100,000 of whom were women and children). ${ }^{25}$ Other commanders, including Nebe, encountered similar difficulties. ${ }^{26}$ After Germans encountered such experiences, the mentally ill were no longer categorized as a "danger" to security, and their execution by firing squad was no longer deemed a priority. The prospective victim pool contracted, and attention shifted to target categories such as Jews, who generated less "burdening of the soul." The irony of the resistance of the mentally ill and the passivity of the "normal" Jews are highlighted in the existing literature. For example, after Einsatzkommando 5 had shot a group of mentally ill patients in Kiev, the men experienced what they termed an accompanying "heavy mental burden." 27 Headland has drawn attention to the apparently "twisted thinking of these men." 
It was "much easier to kill people who were sane." 28 Only the inherently irrational, it seems, were equipped with an effective strategy capable of subverting the increasingly rationalized goal of mass extermination. But it would not last. Despite Einsatzgruppe A's unwillingness to kill the mentally ill, Himmler knew of some specialists who would.

At the request of the Wehrmacht, Himmler decided on 4 October...that Sonderkommando Lange [and his]...gassing vehicles, should be brought by plane to Novgorod in order to kill patients in three psychiatric hospitals there, because the accommodation was urgently needed for troops. ${ }^{29}$

Despite the strain resolving mechanisms they had developed, the executioners and their squad leaders could still not avoid seeing their victims close-up just before and during the shootings. Bauman suggests that the shooters tried to distance themselves as far as possible from their civilian targets. ${ }^{30}$ This strategy, however, created a problem of its own: Less accurate shooting resulted in wounded or in some cases, unwounded civilians falling into the graves with the dead. After the shootings, these victims were buried alive. Some would then try to claw their way out of the graves. But Nazi commanders soon demanded changes. One SS-Commissioner-General complained in a letter to the Reich Minister,

Peace and order cannot be maintained in White Ruthenia with methods of that sort. To bury seriously wounded people alive who worked their way out of their graves again, is such a base and filthy act that this incident as such should be reported to the Führer and Reichsmarschall. ${ }^{31}$

The firing squads' accuracy had to be improved. But to do so the shooters had to move closer to the civilians, but the closer they got, the more they could see and hear them thus intensifying the psychological burden. It was a dilemma. Many years later, a Vietnam Special Forces veteran related his own similar experiences to Grossman. "When you get up close and personal,' he drawled with a cud of chewing tobacco in his cheek, 'where you can hear 'em scream and see 'em die,' and here he spit[s] tobacco for emphasis, 'it's a bitch.' "32 Because Jews were defenseless and often acquiescent civilians, the Germans had opportunities to manipulate their victims in ways that the Vietnam veteran could not. To maximize accuracy, the executioners had to see exactly where they were shooting. One new technique used to alleviate the psychological strain 
associated with the shootings was to have victims turn their backs to the shooters, thus enabling the shooters to avoid any eye contact or see the fearful expressions on their faces. One photo illustrating the German's reliance on this shooting technique taken sometime during the first three months of the Soviet invasion shows at least four men kneeling over the edge of a ditch with a larger number of executioners shooting at the back of their heads from a distance of less than five meters: See https://collections.ushmm.org/search/catalog/pa19151. In Grossman's words,

The eyes are the window of the soul, and if one does not have to look into the eyes when killing, it is much easier to deny the humanity of the victim. The eyes bulging out 'like prawns' and blood shooting out of the mouth are not seen. The victim remains faceless, and one never needs to know one's victim as a person. And the price most killers have to pay for a closerange kill-the memory of the 'face terrible, twisted in pain and hate, yes such hate' - this price need never be paid if we can simply avoid looking at our victim's face. ${ }^{33}$

Also, because with this shooting technique the victims faced away from their executioners, they were less directly forced to hear any crying or screaming. Having the victims kneel instead of stand lowered their center of gravity over the precipice. Thus, upon being shot, they were more likely to fall forward into the grave below. The risk of Germans later having to push (and thus touch) any victims who failed to fall into the grave was reduced. ${ }^{34} \mathrm{~A}$ final slight strain resolving innovation was the introduction of "rotating firing squads," which dispersed the distasteful task across an entire squad. ${ }^{35}$ As Browning argues, this generated enormous pressure on all rank and file members to do their fair share of the dirty work. ${ }^{36}$ It should also be kept in mind that because these Germans stood in potentially hostile enemy territory where all Germans depended on one another for their safety, failing to shoot one's fair share of the victims risked losing their comrade's goodwill. ${ }^{37}$ When contemplating the potential consequences of losing this goodwill, many Germans perceived their decision to shoot over refusing to do so as the lesser of two evils. ${ }^{38}$ Even if a shooter simply proved psychologically incapable of continuing to undertake the executions - thus failing to do their fair share-most important of all was that they demonstrated to their fellow comrades that they at least tried to help out. This intense pressure to participate in the executions, however, only ended up implicating the vast majority of Germans. With nearly all guilty of having killed at least some civilians, 
none of course would ever be in a position to critique the massacres or their fellows' decision to take part in them. ${ }^{39}$

The shooting method of having the victims kneel and turn away, however, was also not without its problems. For example, sometimes victims' skulls would shatter when struck by bullets from close range-a sight the shooters were unable to avoid. ${ }^{40}$ To eliminate problems like this, the neck shot emerged as the "recommended shooting technique...."4l The neck shot required that the victim turn away from the executioner or lie facedown on the ground. Then, from point-blank range, the shooter fired a single shot into the nape of the neck (just above the shoulders). The bullet would enter the back of the neck, producing a small entrance wound and, on severing the victim's spinal cord, kill instantly. With the neck shot, executioners could avoid seeing the larger exit wound. Compared to earlier shooting techniques, the neck shot was un-survivable and clean, and because it resulted in instant death, many Germans perceived it as a more humane way of killing. ${ }^{42}$ For a photo showing a member of Ohlendorf's Einsatzgruppe D relying on this shooting technique, see https://collections.ushmm.org/search/ catalog/pa5355. This photo also suggests that Ohlendorf's early preference for the multiple-shooter-per-victim technique was eventually eclipsed by the more popular neck shot. For another photograph, see https:// en.wikipedia.org/wiki/Einsatzkommando\#/media/File:Einsatzgruppen_ or_their_auxiliaries_-_Kovno_1942.jpg. The neck shot shooting technique likely made it easier for a larger proportion of ordinary Germans to do their fair share of the dirty work.

With fewer psychologically fragile perpetrators and, thus, a larger number of capable ordinary Germans involved in the killings, ambitious leaders in the field continued to seek out more efficient innovations. Probably the most significant development in this direction was Higher SS/Police Leader Friedrich Jeckeln's "Sardinenpackung” method, which developed fairly early in the Soviet campaign near the end of July 1941. August Meier, a "minor bureaucrat," describes the technique.

I still particularly recall an Aktion in Schepetovka which stands out in my mind as extraordinarily gruesome. It involved about a hundred people. Women and children were among those shot. Jeckeln said: 'Today we'll stack them like sardines.' The Jews had to lie layer upon layer in an open grave and were then killed with neck shots from machine pistols, pistols and rifles. That meant they had to lie face down on those previously shot [whereas] in other executions they were shot standing up and fell into the grave or were dragged in. [...] I don't know if Jeckeln did any shooting, but I don't believe so. ${ }^{43}$ 
As Helmut Langerbein observes, Jeckeln's rationale behind this technique was, because the victims stacked themselves, the perpetrators not only maximized usage of the typically limited grave space, they also avoided "the added post-execution work of layering bodies...." 44 As we shall see, with more time and greater experience, this stacking technique inadvertently generated other advantages that enormously increased killing efficiency.

About a month into the Soviet campaign, the Wehrmacht expressed concerns about a sudden influx of Jewish refugees from Hungary into the Ukrainian city of Kamianets-Podilskyi. A Wehrmacht official believed the refugees were too difficult to feed and also posed a "danger of [spreading an] epidemic...." 45 In late August, Jeckeln announced his solution to this problem: By 1 September 1941 he would liquidate them. Jeckeln knew he could not undertake such a massive operation with just his own men, so he organized for other units to converge on the small township. He flew in especially to lead the action, and on the first day, he observed from a nearby hill the mass shooting of 4200 men, women, and children. On the second day, over 11,000 civilians were killed. A total of 23,600 victims had been shot by the massacre's end. ${ }^{46}$ Jeckeln, who on 12 August had been ordered to report to Himmler about his brigade's "lack of 'activity'," 47 radioed Berlin with his body count statistics. According to Dieter Pohl, this late August massacre was "the largest of its kind and signaled a turning point in the Holocaust-a break from killing targeted groups of mostly Jewish males to the indiscriminate murder of entire Jewish communities." 48 Indeed, the massacre brought "Jeckeln the accolades that he had hoped for from his superior." 49 During the month of August 1941, Jeckeln's Kommandostab SS Brigade One, which Breitman notes was not "part of a political-ideological elite" $" 50$ (more moderately antisemitic?), had shot 44,125 civilians in Western Ukraine. ${ }^{51}$ This figure exceeded that of all other police units. ${ }^{52}$ It was from this point on that the "curve of murder statistics" soared.

In terms of the broader military campaign in the East, September 1941 was a particularly good month for the Wehrmacht.

...Leningrad was successfully cut off in early September. The Ukrainian campaign that Hitler imposed on his reluctant generals quickly followed. On September 12 Ewald von Kleist's tanks broke through the Soviet lines behind Kiev. On the same day German forces cracked the defensive perimeter around Leningrad. In the words of Alan Clark, this day could be "reckoned the low point in the fortunes of the Red Army for the whole war." By September 16 Kleist had joined up with Heinz Guderian at 
Lokhvista to complete the vast Kiev encirclement. By September $26 \mathrm{Kiev}$ had fallen and 665,000 Soviet prisoners had been taken. ${ }^{53}$

With the Soviet Union at such a low point, Hitler sensed that total control of Europe would soon be his. In the "euphoria of victory," 54 Hitler, brimming with confidence, suddenly reversed his earlier decision not to expel the German Jews unable or unwilling to leave the Reich. ${ }^{55}$ Hitler's decision may also have been influenced by Karl Kaufmann, the Gauleiter of Hamburg, who in September apparently asked the Führer if he would deport Germany's Jews so that their apartments could be used to house Germans whose homes had been destroyed by British bombing raids ${ }^{56}$ - bombings Nazi propaganda blamed the Jews for. ${ }^{57}$ Whatever the reason behind this change, Hitler's decision (as we shall soon see) sparked Eichmann, the so-called Nazi's people mover, into sudden activity. Because, as shown, most Germans benefited financially and materially from the Nazi military victories, perhaps the Nazi labor minister's demand around September 1941 that the pension gap between white- and blue-collar (Aryan) Germans be narrowed is unsurprising. ${ }^{58}$ A month later and with more military successes, on 4 October 1942 Göring was the bearer of more good news for Germany: "From this day on things will continue to get better since we now possess huge stretches of fertile land. There are stocks of eggs, butter, and flour there that you cannot even imagine." 59 Not publicly discussed, of course, was what diverting this food bonanza to Germany and its armed forces meant for those living in and around these fertile lands. A month before Göring's good news, in August 1942 Erich Koch (Reich Commissioner for Ukraine) had already cemented his food policy guidelines, stating:

Ukraine is required to provide everything Germany lacks. This requirement is to be fulfilled without regard to casualties .... The increase in bread rations is a political necessity crucial to our ability to pursue the war to its victorious conclusion. The grain we lack must be extracted from Ukraine. In light of this task, feeding the civilian population there is utterly insignificant. ${ }^{60}$

As the Wehrmacht continued to push further into the Soviet interior, not far behind came Jeckeln efficiently executing unusually large numbers of Jews. In early September, Jeckeln's HSSPF Russia South shot 4144 Jews in the Ukrainian township of Berdychiv. ${ }^{61}$ A week or so later, 
his men, accompanied by Police Battalion 45, killed another 12,000 Jews. Most of the victims were women, children, and the elderly. ${ }^{62}$ Wherever body counts were unusually high, Jeckeln could be found. The secret behind Jeckeln's ability to rapidly wipe out entire communities was the advancing organizational process he attached to his "Sardinenpackung" shooting technique.

\section{The Bureaucratized Mass Shooting Process: Babi Yar}

On 19 September 1941, an advanced party from Paul Blobel's Sonderkommando 4a (Einsatzgruppe C) arrived in Kiev. ${ }^{63}$ The city was home to Ukraine's largest Jewish population. At a meeting between Jeckeln, Blobel, and Kurt Eberhard, Jeckeln set his sights on eliminating Kiev's entire Jewish population and arranged for other units, including some Ukrainian auxiliaries, to help with the task. ${ }^{64}$ Soon after, announcements on the streets of Kiev instructed all members of the Jewish community to meet at $8 \mathrm{a} . \mathrm{m}$. on 29 September at a particular downtown location. All Jews were to bring official documents, warm clothing, linen, and any valuables. Those who failed to show up would be hunted down and shot. On the appointed day, a large crowd gathered. German and Ukrainian forces arranged them into a purposefully staggered line. Then, according to eyewitness Sergei Ivanovich Lutzenko, "in tight columns of one hundred each" the Jews "were marched to the adjoining Babi Yar" ravine. ${ }^{65}$ Another account by Lev Ozerov notes that at Babi Yar "an entire office operation with desks had been set up...."66 A truck driver named Höfer describes what he saw:

The Ukrainians led them past a number of different places where one after the other they had to remove their luggage, then their coats, shoes and overgarments and also underwear. They also had to leave their valuables in a designated place. There was a special pile for each article of clothing. It all happened very quickly and anyone who hesitated was kicked or pushed by the Ukrainians to keep them moving. ${ }^{67}$

Removing the victims' clothing before shooting them generated two main advantages: the clothes could later be sold on for profit and, in terms of control, earlier executions confirmed that naked victims were less likely to make a run for it. ${ }^{68}$ The Babi Yar ravine, 
was about 150 metres long, 30 metres wide and a good 15 metres deep. Two or three narrow entrances led to this ravine through which the Jews were channeled. When they reached the bottom of the ravine they were seized by members of the Schutzpolizei and made to lie down on top of the Jews who had already been shot. This all happened very quickly. The corpses were literally in layers. [...] When the Jews reached the ravine they were so shocked by the horrifying scene that they completely lost their will. It may even have been that the Jews themselves lay down in rows to wait to be shot. [...] there was a 'packer' at either entrance to the ravine. These 'packers' were Schutzpolizisten, whose job it was to lay the victim on top of the other corpses so that all the marksman had to do as he passed was fire a shot. ${ }^{69}$

The packers helped to ease the psychological burden on the shooters by ensuring victims were facedown and thus faceless, robbing them of their individuality. ${ }^{70}$ There were so many people to kill that the shootings continued until darkness, with the action resuming at first light the following morning. ${ }^{71}$ Paul Blobel divided his men into groups of 30 , with each group spending an hour each on shooting duties. ${ }^{72}$ With specialist contributors who collected clothing and valuables, channeled victims into the ravine, and "packed" the victims to await the arrival of the marksmen who shot them, Jeckeln had developed a bureaucratized, assembly-line process of mass murder. With more civilians killed in less time, this massacre overshadows that in Kamianets-Podilskyi. Despite Jeckeln's record-breaking feat, his report to Berlin tersely noted, "Special commando 4a, together with Einsatzgruppe C Headquarters and two commando groups of the South Police Regiments, executed 33,771 Jews in Kiev on 29 and 30 September 1941."73

At the same time that Nebe and Fritzsch were undertaking their gassing experiments, Jeckeln's application of means-to-end formal rationality enabled him to destroy a greater number of civilians than any other unit yet. A secret official report noted at the time that the key to this staggering result was Jeckeln's application of some "extremely clever organization" to overcome the usual "difficulties resulting from such a large-scale action." 74 As Yaacov Lozowick observes, "It seems no accident that the orderly, well-planned murder of 33,000 Jews took place at Kiev at the end of this period, rather than at Lvov near the beginning." ${ }^{75}$ Much like Milgram would later do at Yale during his pilot studies, project manager Jeckeln also gradually and systematically refined his procedure of harm 
infliction. And with more time, Jeckeln's "factory-orientated approach"76 underwent further refinements; the division of labor increased with ever more specialist functionaries performing ever more refined specialist tasks, including a reliance on specialist shooters who were willing and capable of doing more than their fair share of the dirty work. ${ }^{77}$ At a mass shooting eight weeks after the Babi Yar massacre,

In the pits...there were to be only a few active marksmen, each of whom used a machine pistol set on single shot. Walking over his victims, a "shooter" could fire fifty shots and then receive a new magazine from a comrade whose sole responsibility was refilling cartridges [...] After a number of magazines, the marksmen would take a break. Row after row, marching block after marching block was to be killed in this manner, in accordance with Jeckeln's minutely worked out method.... ${ }^{78}$

Thus, as Angrick and Klein put it, with time and increasing experience Jeckeln came to prefer deploying in the pits "a small circle of truly emotionless SS men," "primarily his 'old' men...who had 'already done' something like this" at earlier executions. ${ }^{79}$ Still, due to the highly stressful nature of such work, Jeckeln felt it was necessary to rotate with "additional men for the relief...." 80

Because, during the campaign, Jeckeln received the aid of various military units-Wehrmacht regiments, Einsatzkommando units, Police battalions, and Ukrainian auxiliary forces-his "one best way" of massacring civilians soon spread elsewhere. If Germans in the armed forces decided in the future to deploy Jeckeln's "controlled" shooting process-and as we shall see, they did- "calculable" and highly "efficient" results of around 15,000 people killed per day became "predictable." Jeckeln's inherently bureaucratic mass shooting process advanced all four components of a formally rational system. ${ }^{81}$ It is Jeckeln's process (along with the innovations by other contributors, like Einsatzkommando 3's Karl Jäger) that best explains the rising curve of murder statistics in the Soviet interior after mid-August 1941. And Jeckeln's increasingly bureaucratized shooting process - with its division of labor, specialization of labor, clear responsibilities, written records, rules and procedures, impersonality of relations - could do so because as Weber argues,

The decisive reason for the advance of bureaucratic organization has always been its purely technical superiority over any other form of organization. 
The fully developed bureaucratic mechanism compares with other organizations exactly as does the machine with the non-mechanical modes of production. ${ }^{82}$

I therefore challenge the so-called de-bureaucratization argument during the Holocaust by bullets. ${ }^{83}$ In fact, the rational evolution of the execution process and the record-breaking Babi Yar massacre in particular can, I believe, be described more precisely as a modern bureaucratic process.

Despite the increased bureaucratization, an earlier problem persisted. Even some of the "ordinary" executioners, who after several months of killing had risen to the top of Himmler's shooter attrition process, were still in need of, as Jeckeln put it, "relief...." For example, Kurt Werner, a marksman at the Babi Yar massacre, admitted after that, "It's almost impossible to imagine what nerves of steel it took to carry out that dirty work down there. It was horrible...." 84 Like the Obedience study's Mrs. Rosenblum, Werner only seems concerned about his pain. With a seemingly endless supply of Soviet Jews to kill, the question was how much longer could the most calloused of German killers like Werner keep it up? Shooting squad reports such as the one Jeckeln submitted to Berlin after Babi Yar rarely mention any psychological problems among the perpetrators. However, as Headland noted earlier, officials were constantly aware of the issue and gave it a great deal of attention. ${ }^{85}$ As Rudolf Höss said after the war,

Many gruesome scenes are said to have taken place, people running away after being shot, the finishing off of the wounded and particularly of the women and children. Many members of the Einsatzkommando [Nazi shooting squads], unable to endure wading through blood any longer, had committed suicide. Some had even gone mad. ${ }^{86}$

In confirmation of much of this, in November 1941, lawyer Helmuth von Moltke wrote in a letter to his wife that at least one hospital existed "where SS men are cared for who have broken down while executing women and children." 87 A Wehrmacht neuropsychiatrist who treated many of those affected believed that about $20 \%$ of men suffered from psychological disorders associated with the shootings. ${ }^{88}$ Even those German executioners who did not break down, as Annette Schücking, a female aid based in the East, reported, "all had an intense need to talk." $" 89$ 
Despite the ongoing psychological problems, Jeckeln still proved capable of obtaining high body counts. Perhaps this is why on 10 October 1941, Heydrich mused about deporting Germany's Jews to new camps in Einsatzgruppe C's area of operations in Ukraine. ${ }^{90}$ It is no coincidence that Einsatzgruppe $\mathrm{C}$ happened to fall under Jeckeln's umbrella of control. ${ }^{91}$ Indeed, a week later, on 18 October, after meeting with the General Government's SS and Police Leader FriedrichWilhelm Krüger and the previously mentioned Odilo Globocnik, Himmler ordered the cessation of Jewish emigration. ${ }^{92}$ Himmler would now be in charge of when the Reich Jews would leave Germany and where they would be sent. In reaction to Hitler's earlier decision during the September "euphoria of victory," around mid-October the RSHA (Eichmann) started organizing trains packed with German and Austrian Jews (from cities including Berlin, Munich, Frankfurt, Vienna, and Breslau) to start rolling east. However, somewhat mysteriously, the plan to send German Jews to Ukraine was soon dropped. Instead, these trains were redirected to Minsk (Belarus), Kaunas/Kovno (Lithuania), Riga (Latvia), and, most proximately, Lódź (Poland). In the German university town of Göttingen, locals-presumably victims of British air raids - reacted to this news by "flooding" the NSDAP district office with applications for the soon-to-be-vacated Jewish apartments. ${ }^{93}$ Because these German Jews were limited to leaving with no more than 50 kilograms of luggage, ${ }^{94}$ the household effects they had to leave behind-furnishings, appliances, textiles, and such-were passed on to "deserving" Germans. ${ }^{95}$

The deportation of trainloads of these Western Jews to various eastern cities signaled significant movement in the Nazi regime's solution to the "Jewish question." Eichmann, the SS's people-moving expert, knew that if the SS was to succeed, it would need to draw on the expertise, resources, and support of other German governmental agencies. But doing so would require that the usually secretive SS discloses its intentions to others. With such cooperation in mind, on 29 November Eichmann sent invitations on Heydrich's behalf to almost a score of mostly high-ranking civil servants from certain government agencies, for example, the Transportation Ministry. The meeting, scheduled for 9 December, has become known as the Wannsee Conference. ${ }^{96}$ Heydrich attached to the invitations a 31 July 1941 mandate from Göring ${ }^{97}$ that reinforced that he (Heydrich) had total control over resolving the Jewish question, ${ }^{98}$ and therefore, all invitees were to cede to his needs. Those 
invited were the people whose acquiescence Heydrich would demand, and whose help and resources Eichmann would need, to resolve once and for all the persistent and expanding "Jewish question." And it was at this meeting that a new plan would be revealed.

But soon after the invitations were sent out, Germany was struck by several significant blows on the military front lines. First, in the Soviet interior, the onset of winter from about November 1941 saw the Nazi war machine grind (freeze?) to a halt. Then, beginning on 5 December the Soviets managed to muster a forceful counteroffensive. Germany's lightening victory over the Soviets would not come as easily as Hitler had so confidently anticipated. The resumption of the successful march to victory would have to await the spring thaw. The second and immediately more disconcerting blow to the German military came just a few days later on 7 December 1941 when the Japanese attacked Pearl Harbor-an act which caused the USA to declare war on Japan. Due to the Axis Pact between Italy, Japan, and Germany, the USA's declaration of war against Japan required Germany to declare war against the USA. If the USA could free itself from a predictably difficult campaign against the Japanese in the Pacific, the already stretched Nazi war machine would face, on multiple front lines, a new, highly industrialized, and no doubt awesome foe.

In response to these military setbacks, on 12 December 1941, Hitler, according to Goebbels' diary, "decided to make a clean sweep [of the Jews]." 99 An entry in Himmler's diary, dated 18 December, confirms that around this point in time the policy toward all Jews changed. "Jewish question | exterminate as partisans." 100 For the previous six months, Soviet Jews had been the targets of genocidal actions, so this statement was obviously not specifically directed at them. Powerful Jews in the Reich, Europe, and America were, as far as Hitler was concerned, behind Germany's recent military setbacks. ${ }^{101}$ All such groups, at least those within reach, would now pay the price.

But how exactly were all the Western Jews transported to the East to be killed? As shown, over the previous few months, a variety of trial-and-error experiments had taken place-some of which indicated strong signs of probable success. Still, as Hilberg argues,

As of November 1941, there was some thinking about deporting Jews to the Einsatzgruppen so they could be killed by these experienced shooters. That is why German Jews were transported to Minsk, Riga, and Kovno. ${ }^{102}$ 
If so, why were most of these cities located in Einsatzgruppe A's northwestern sphere and none in Jeckeln's southwestern territories? Put differently, why was the Nazi's most effective executioner being excluded from this tentative plan? The answer to this question is that he was not excluded-in mid-October 1941 Himmler decided to replace HansAdolf Prützmann (Higher SS and Police Leader of Northern Russia) with the far more "efficient" Jeckeln. ${ }^{103}$ By November, Jeckeln, with his team intact, had relocated to the north (based in the Latvian capital of Riga). ${ }^{104}$ According to his own testimony after the war, nearing mid-November Jeckeln received orders from Himmler for his first assignment: liquidate the 25,000-28,000 Latvian Jews in the Riga ghetto incapable of productive labor. ${ }^{105}$ For this assignment, Jeckeln intended to apply his trusted "Kiev model...." $106 \mathrm{He}$ settled on a site in a clearing in the Rumbuli forest about 10 kilometers south of Riga. ${ }^{107}$

On 25 November 1941, about 250 kilometers south of Riga, the first of the Reich Jews arrived on Eichmann's trains at the Lithuanian city of Kaunas. The nearly 3000 German Jews on board-mainly women and men and a small number of children-were met by Karl Jäger's efficient Einsatzkommando 3 and were soon after shot. ${ }^{108}$ Back in Riga, on 30 November Jeckeln implemented his plan to liquidate the Latvian Jews in the Rumbuli forest. But the previous evening a train with 1000 Jews from Berlin arrived. ${ }^{109}$ On his own initiative, Jeckeln decided to also kill the new arrivals first thing in the morning, instead of housing them in the recently vacated Riga ghetto as planned. ${ }^{110}$ Einsatzgruppe A's Dr. Rudolf R. Lange (not to be confused with T4's Herbert Lange) tried to defy Jeckeln's decision. Lange not only stood up to Jeckeln but also informed both Heydrich and an immediately furious Himmler what was taking place. Himmler's order to Jeckeln that this particular trainload of Jews was not to be shot arrived too late-all were killed earlier in the day. It is not clear why Himmler wanted to save, for the meantime, this particular transport. ${ }^{111}$ What is clear is that although many more trainloads of Western Jews soon followed, most were not shot. Instead, these Reich Jews were housed in the Lódź, Minsk, and Riga ghettos. ${ }^{112}$ Indecision in the Eastern territories seems to have set in. As Browning notes, "In the last months of 1941, the total mass murder of the deported Reich Jews was clearly not yet being implemented."113

One explanation for the hesitancy is that the onset of winter made grave digging in the permafrost impossible. ${ }^{114}$ This may be part of the answer, although such conditions did not seem to stop Jäger and 
Jeckeln's winter massacres. ${ }^{115}$ Much of this mystery must then be explained by the fact that the shooting squads were struggling with the increased psychological burden associated with having to shoot Western Jews. Wilhelm Kube, the Generalkommissar for White Ruthenia based in Minsk, highlighted the problem when he noticed that two young Jewish women from Germany appeared to have fully Aryan features. Although in the 1930s, he was rightfully described by one scholar as "an inveterate antisemite"116 — and described Minsk Jews as "indigenous, animalistic hordes"117 — it appears Kube developed strong second thoughts about the "Final Solution" when it came to shooting Jews from "our cultural milieu."118 And until "a more discrete and 'humane' way" could be found, Kube refused to shoot Reich Jews. ${ }^{119}$ Soon after, however, Heydrich overruled Kube's reluctance and these Western Jews were eventually shot. But of course, for those implementing these orders, if the most seasoned of German executioners struggled to kill every Eastern Jew placed before them, it is not difficult to imagine they faced heightened psychological difficulties when ordered to shoot civilians from the west who dressed, sounded, and sometimes looked much like themselves. Most of these Jews did not resemble the images promoted in Nazi propaganda: poor Eastern Jews whose impoverished appearances were a side effect of the wartime condition imposed on the ghettos by the Nazis themselves. Perhaps Jeckeln could find a solution. However, it appears the SS-Reichsführer was quickly losing faith in his chief executioner. At a meeting on 4 December, Himmler told Jeckeln:

shooting is too complicated an operation...For shooting, he [Himmler] said, one needs people who can shoot, and...this affects people poorly, therefore Himmler said further, it would be best to liquidate the people by using gassing vehicles, which had been prepared in Germany according to his instructions, and that by using these gassing vehicles the troubles connected with shooting would fall to the wayside. ${ }^{120}$

For Jeckeln, more bad news followed. The day before this meeting Rudolf Lange was promoted to Chief of the KdS Latvia. ${ }^{121}$

Of course, it was from September 1941 Höss's Zyklon-B gassing technique and Nebe's gas van innovations held the potential to provide an apparently more "humane" means of killing civilians. By the time of the above meeting between Himmler and Jeckeln, the SS in Berlin had already placed an order with Prüfer from Topf \& Sons for a 
crematorium to be built in Mogilev (near Minsk), ${ }^{122}$ which, according to Gerlach, they intended to combine with a gas chamber "not to kill the remaining local Jews but those of Western and Central Europe."123 An extermination camp for Jews was being planned for Mogilev, ${ }^{124}$ and since the German military had priority use over the Soviet railway, the emerging plan was to transport the Jews to the camp by boat along the Bug, Pripet, and Dnieper rivers. ${ }^{125}$ In fact, in Mogilev, "Not only was a large crematorium ordered, but HSSPF Hamburg Rudolf Querner apparently also ordered large quantities of Zyklon-B gas from Tesch \& Stabenow, and HSSPF Ostland in Riga [Jeckeln] expected this gas to be delivered." 126 If, indeed, Jeckeln supported this delivery of Zyklon-B to Mogilev, it would suggest that even he conceded that gassing was probably the more preferable means of killing Western Jews. The decision to use gassing technology in Minsk (stationary chamber) and gas vans in Riga on "Old Reich" Jews "not fit for work" can be traced to a letter written by Erhard Wetzel (racial advisor in the Eastern Ministry) to Hinrich Lohse (Reichskommissar for the Ostland) on 25 October 1941:

...[T4's Victor] Brack of the Führer's Chancellery has already declared himself willing to work on the production of the required accommodation as well as the gassing apparatus. ${ }^{127}$

Gas vans were indeed sent to Riga and parts for Prüfer's crematorium were delivered to Mogilev where they sat awaiting construction. Infrastructure along the waterways had been too badly damaged for boat transport, and as a result, in 1942 the plan was abandoned. ${ }^{128}$

Also important, by early December 1941, as Himmler spoke to Jeckeln, Nebe's gas vans had already started rolling off the production line and were being sent to the East. Therefore, as Himmler implied at this meeting, he no longer needed Jeckeln's specialist skill-set at the last link in the machinery of destruction. With other options on the horizon, the problematic shootings were no longer needed and Jeckeln's star role in Nazi Jewish policy was over. Pending the arrival of the vans, leaders like Kube passed on the usual shooting duties to their Latvian and Lithuanian collaborators. ${ }^{129}$ Kube's solution actually highlights what, in the absence of the new killing technology, became the German executioners' most popular self-invented strain resolving coping mechanisms that reduced (eliminated?) their "burdening of the soul." 


\section{The Insertion of “[E]Nd [S]pecial [U]nits"}

From the start of the Soviet campaign, Himmler noticed that even without guns antisemitic Eastern Europeans still seemed far more eager than his own men to attack Jews. What more could he gain from arming them? It seems Himmler raised this possibility in Berlin during Hitler's 16 July 1941 "Garden of Eden" meeting; however, the Führer was adamant that Eastern Europeans should never be armed. ${ }^{130}$ But, toward the end of that month, as his Kommandostab SS Cavalry Brigade desperately herded Jewish women and children into the shallow Pripet quicksands, Himmler disobeyed Hitler's order by copying the German security police's early July initiative to set up a battalion of Lithuanians and placing them under the control of Jäger's Einsatzkommando 3. On July 25, Himmler officially "authorized the creation of auxiliary police forces from the reliable non-Communist elements among Ukrainians, Estonians, Latvians, Lithuanians, and Byelorussians." $131 \mathrm{He}$ did so because, in his words, "the task of the police in the occupied eastern territories cannot be accomplished with the manpower of the police and SS now deployed or yet to be deployed."132 However, as Breitman observes, the Eastern collaborators,

and their future use as executioners reflected more than just a shortage of German policemen. Whereas Himmler, Daluege, Bach-Zelewski, and some other high officials had some concerns for the morale of German police, they did not much care what happened psychologically to the non-Germans as long as there were enough of them to carry out their appointed tasks. [italics added] ${ }^{133}$

Simply increasing German manpower was unlikely to work, but Himmler suspected that augmenting Eastern European manpower might. Himmler's disobedience may, therefore, be explained by his suspicion that Eastern Europeans might make better executioners than ordinary Germans. By the end of 1941, 33,000 Eastern European collaborators had joined German extermination squads. ${ }^{134}$ Six months later, the number had risen to 165,000 , and by January 1943, it had almost doubled to $300,000 .{ }^{135}$ However, simply arming large numbers of Eastern Europeans was, by itself, inadequate. In the spirit of Weberian formal rationality and means-to-end logic, the task at hand demanded meticulous organizational preparation. ${ }^{136}$ Under the careful management of 
German authorities, Eastern European collaborators were slotted in as the last link in the Nazis' shooting assembly line where they could efficiently perform their specialist labor.

A mass shooting undertaken in August 1941 in the Ukrainian village of Belaya Tserkov illustrates the kind of roles given to collaborators. After German soldiers shot all the men and women, and two of the boys, the rest of the children were held in a house without food or water until Ukrainian auxiliaries were brought in to shoot them. However, the Ukrainians left behind the 90 or so children under the age of sevenmainly toddlers and babies. According to Blobel's subordinate, August Häfner,

...Blobel ordered me to have the children executed. I asked him, 'By whom should the shooting be carried out?' He answered, 'By the WaffenSS.' I raised an objection and said, 'They are all young men. How are we going to answer to them if we make them shoot small children?' To this he said, 'Then use your men.' I then said, 'How can they do that? They have small children as well.' This tug-of-war lasted about ten minutes. [...] I suggested that the Ukrainian militia of the Feldkommandant should shoot the children. There were no objections from either side to this suggestion.... ${ }^{137}$

Regarding the proposed execution site, Häfner continued,

The Wehrmacht had already dug a grave. The children were brought along in a tractor. $[\ldots]$ The Ukrainians were standing round trembling. The children were taken down from the tractor. They were lined up along the top of the grave and shot so that they fell into it. The Ukrainians did not aim at any particular part of the body. They fell into the grave. The wailing was indescribable. I shall never forget the scene throughout my life. I find it very hard to bear. [...] Many children were hit four or five times before they died. ${ }^{138}$

Blobel, presumably having recovered from his mental breakdown a month earlier, clearly had no qualms about ordering the Ukrainians to undertake this mass execution. Perhaps unsurprisingly, however, he chose not to attend.

Eastern Europeans were increasingly given the tasks of shooting women and children, which Germans often shied away from. ${ }^{139}$ As one member of Einsatzgruppe A stated, 
The orders for the third or fourth Einsatz were particularly important because they gave instructions for members of the local population to be used to carry out the actual dirty work, to which end special units should be set up. The purpose of this measure was to preserve the psychological equilibrium of our own people.... [italics added $]^{140}$

Although German supervisors and executioners may not have liked to admit it, the locals in these "end special units" (i.e., the last and most stressful link in the Nazi's destructive bureaucratic chain) were responsible for producing some of the bleakest statistics. For example, the Jäger report (which lists the deaths of over 130,000 civilians killed in under five months) states the massacres were undertaken by only eight to ten "reliable" Germans in "cooperation with Lithuanian partisans...."141 As Matthäus said of the Lithuanians under Jäger's control, "these men contributed massively towards the staggering figure...." ${ }^{142}$ MacQueen concludes that,

Jager's "achievement" has to be considered largely as a triumph of managing the Lithuanian Schutzmannschaft forces (some 8000 men by the end of 1941) and the Lithuanian Police, without whom this deadly work would not have been remotely possible. ${ }^{143}$

In fact, during the liquidation of the Riga ghetto even Jeckeln trialed Jäger's most prized innovation when he supplemented his specialist German marksmen with a rapid rotation of Latvians. The rotation, however, did not last very long because most of the Latvians became too drunk to adequately perform their specialist role. ${ }^{144}$

It seems, then, that the most common strategy German authorities adopted to prevent members of their execution squads from becoming, in Bach-Zelewski words, "neurotics or savages," was one that shielded German perpetrators from all perceptual engagement. As a security police interpreter in Liepaja stated, "It was only in the early days that members of our section had to man the firing-squad. Later we had a Kommando of Latvians who made up the firing-squad." 145 The reason this strategy proved so popular among German troops is not hard to guess. Just as in Milgram's Peer Administers Shock condition, where an actor fulfilled the role of shock-inflictor, it enabled all Germans across the division of labor to make essential contributions to the overall process (victim capture, roundup, cordon duty, and so on) without feeling 
(or appearing) personally responsible for the deadly outcome. This strategy powerfully promoted responsibility ambiguity among all Germans involved. As Wendy Lower put it, with the help of non-German shooters, "Even at the lowest level of the Nazi hierarchy, one could play one's part in the 'final solution' without dirtying one's hands...."146

The use of Ukrainians, Latvians, Lithuanians, and other collaborators at the killing-end of the assembly line (the most destructive of whom were, for obvious reasons, eagerly sought by the Germans outside their homelands as "end special units" ${ }^{147}$ ) raises another question. If the psychological strain generated by shooting civilians was as debilitating as many Germans attested after the war, why did these collaborators not experience comparable levels of strain and trauma? One possible reason may be, as Bauer noted earlier, that German perpetrators came from a mildly antisemitic society, while these collaborators were much more violently antisemitic. To ensure that the orders of those in Berlin were met, the Germans frequently required the help of those from certain Eastern European nations who had indisputable reputations for hating Jews and may have been more willing to act on such feelings. Another possible reason might be, as Jeckeln noted during his trial after the war, "Latvians were excellent for the job of murdering Jews, since they had strong nerves for executions of that sort." 148

However, there is evidence that Eastern European collaborators struggled with the psychological burden of killing as much as anyone else, as their proclivity for drunkenness during executions suggests. But perhaps the strongest explanation is that in the wake of Operation Barbarossa, many Eastern European soldiers became prisoners of war and could only win release if they agreed to do the Germans' dirty work. And release meant they were less likely to die from starvation. ${ }^{149}$ Again relying on the colonial management technique of favored natives obtaining privileges in exchange for controlling the others, as Göring himself said, the only non-Germans to be fed during the Soviet invasion were those "performing important tasks for Germany." ${ }^{50}$ Many Eastern European "end special units," therefore, likely also struggled psychologically with the shootings, but continued to participate in a desperate effort to secure their own survival.

Whatever the numerous and no doubt overlapping reason(s) the Eastern collaborators had for participating, this kind of analysis only serves to draw attention away from the key instigators-the Germans. 
Here Breitman draws attention back to the Nazi regime and its rational and creative bureaucrats,

After the war Erich von dem Bach-Zelewski explained that the extermination camps arose because Germans and Central Europeans were not suited to be mass executioners. Stalin, he said, always had people to employ for this purpose-for example, the Latvians. Although the Nazis found some individuals to serve as killers, there was no collective eagerness to do so. The extermination camp...was something that the Russians could not accomplish: it reflected the German gift for organization. Bureaucrats created it, he concluded. ${ }^{151}$

\section{Conclusion}

In an attempt to ease the psychological burden of shooting civilians, the field leadership and their men introduced a variety of strain resolving coping mechanisms aimed at reducing the perceptual intensity of the mass shootings. These bottom-up techniques, including the consumption of alcohol, a focus on shooting the most compliant victims, evolving shooting techniques, and, after the bureaucratization of the shooting process, a dependence on Eastern European "end special units," powerfully aided the advance toward what Milgram would later term (perceptual) avoidance. This, in a nutshell, is how the German perpetrators coped with what Hilberg described as "weighty psychological obstacles and impediments," and over time helped them avoid becoming "neurotics" or "savages...." 152

As the shooting squads' most effective strain resolving mechanisms spread, the body count grew, and the closer these men came to achieving the desires of their leaders far away in Berlin. As Lower points out, from the top-down Hitler, Himmler, and Heydrich defined and pushed in favor of the "final solution." Implementation, however, came through the bottom-up initiatives of those in the field in the lower and middling ranks. ${ }^{153}$

This process reminds us of Milgram's pilot studies where he decided to replace the translucent screen with a solid wall and, as a consequence, enhanced the psychological ability of a greater proportion of his participants to implement his top-down desires. Indeed, as mentioned, Milgram's idea to introduce a wall in the official experiments was instigated by his participants (thus from the bottom-up), who looked away 
from the learner in order to make it psychologically easier for them to inflict more shocks.

"The primary question concerning the Holocaust as a crime based on the division of labor is..." according to Michael Allen, "[w] hat interrelationship existed between centralized authority and spontaneous initiative at the local level?" 154 A convincing answer to this question would seem to go a little further than the "rule of anticipated reactions," or what regional functionaries in the East themselves referred to as "anticipatory obedience." 155 The leadership set policy goals and upper-level field management (Jeckeln, Jäger, Ohlendorf, and their problem-solving ilk) discovered strain resolving and efficient techniques, the introduction of which was probably motivated by a mix of coercive pressure from the SS leadership, their own personal ambitions, and a desire to ensure their subordinates did not become "neurotics or savages."156 Also, motivated by a desire to ease their own stress, sometimes the executioners contributed to the banalization of the shooting techniques. As the most directly involved perpetrators found their tasks psychologically more bearable, they were able to perform them longer and, as a result, came ever closer to achieving the desires of the leadership in Berlin.

Using the terminology of organizational theorists, the emergence of the sufficiently banal shooting techniques was of crucial importance because the less stressful the executions became, the more likely the German shooters could remain within their Zone of Indifference. And once able to remain within the Zone of Indifference and thereby having accepted their new destructive roles, then their creative internal rationalization machine - much as outlined by Albert Bandura's theory of moral disengagement-was able to exert "self-influence." The shooters would, for example, tell themselves and other Germans that they were, for example, fighting for the Reich's survival, and because Jews kept breaking the rules of occupation, all were-as Hitler and Himmler said from the start- "partisans" and "criminals" worthy only of death. The logical conclusion of all such rationales was the same: "what we are doing is necessary." 157 Of course, the German shooters had so much power over life and death decisions that nobody in the occupied territories could or would dare inform them that following the rules of occupation (like never leaving a barren ghetto) was in itself a death sentence that forced Jews to become "partisans" and "criminals." 158 
Crucial in making all this possible was the process of rationalization that saw the mass shootings become an increasingly bureaucratic process. As Bauman states,

Once the objective had been set, everything went on exactly as Weber, with his usual clarity, spelled out: "The "political master" finds himself in the position of the "dilettante" who stands opposite the "expert", facing the trained official who stands within the management of administration.' The objective had to be implemented; how this was to be done depended on the circumstances, always judged by the 'experts' from the point of view of feasibility and the cost of alternative opportunities of action. ${ }^{159}$

As subsequent chapters will show, advancing formal rationality where certain experts made the killing of civilians both more efficient and less offensive only continued, thus enabling the Holocaust to reach ever greater and more devastating heights.

Although the use of guns was labor intensive, involved complex logistics, and was hard to keep hidden from public view, with time and experience, it nonetheless proved capable of killing civilians on a horrendous scale. Despite an initially slow start to the shooting campaign, by the end of the war this method of extermination had killed about $25 \%$ of all Jewish Holocaust victims. The number of Roma (Gypsies) shot is not clear but likely numbered in the tens of thousands. ${ }^{160}$ But as far as the leading Nazis were concerned, the major limitation of firearms was that their men were forced to witness an undeniable connection between their contributions and their lethal effects. The main shortcoming of guns was that they made many of the German executioners feel and appear too responsible for their actions - there was insufficient responsibility ambiguity at the last link in the organizational chain. The resulting responsibility clarity stimulated among some executioners intense feelings of guilt and, most commonly, repugnance (feelings that varied in intensity, depending on the type of victim). While throughout the war the Nazi regime never completely abandoned this highly mobile method of killing, as 1941 came to an end it was clear that firearms alone could not provide any long-term "solution" to the Nazi's now European-wide "Jewish problem," 161 especially when many of the victims dressed, sounded, and often looked like the perpetrators. What was needed instead was a more impersonal, less public, less labor intensive, and even more industrial and organized method of mass extermination. When Himmler dumped Jeckeln in early December 1941, the SS-Reichsführer clearly sensed that a new method was on the horizon. 


\section{Notes}

1. Bauman (1989, p. 105).

2. Poliakov $(1979$, p. 123, as cited in Markusen and Kopf 1995, p. 134).

3. Kwiet (1998, p. 10).

4. Neitzel and Welzer (2012, p. 113).

5. Kwiet (1998, p. 10).

6. Musmanno (1961, p. 76).

7. Similar avoidance-type strain resolving techniques developed elsewhere. For example, the Black Wall of Auschwitz may have been painted this color because it hid, to some degree, the gradually accumulating and unsettling blood, bone, and brain-splatter that might otherwise remind the executioners of the extremes of their actions. In a similar way, prisoners accompanied with shovels were instructed by the shooters to cover "the foaming pools of blood with sand after every pair of executions" (Naumann 1966, p. 168).

8. Desbois $(2008$, p. 139).

9. The technique was used during the Polish invasion (see Hochstadt 2004, pp. 90-91).

10. Kwiet (1998, p. 7).

11. Kwiet (1998, p. 20).

12. Kwiet (1998, p. 20).

13. Hilberg (1961, p. 249). One Einsatzgruppen member said "We could only stand it drunk. We believed that we had to shoot our way through to the Ural Mountains" (quoted in Langerbein 2004, p. 186).

14. Dicks (1972, p. 207). Alcohol is a powerful strain resolving tool because, as Baumeister (1997, p. 342) suggests, it has two overlapping effects: "First, it seems to produce low-level thinking. When people get drunk, their thinking becomes narrow, rigid, and concrete, and this focus minimizes thoughts of grand principles (such as morals) and the emotions that accompany them. Second, alcohol tends to deflect thinking away from the self, and so one does not dwell on issues of identity and responsibility."

15. Quoted in Klee et al. (1988, p. 62).

16. Quoted in Klee et al. (1988, p. 62).

17. Quoted in Klee et al. (1988, p. 97).

18. Quoted in Klee et al. (1988, p. 60).

19. Quoted in Klee et al. (1988, p. 140). See also Angrick and Klein (2009, p. 156) and Hilberg (2003, p. 329). One German executioner believed Jewish women about to be shot were generally calmer than the men during their last moments (Neitzel and Welzer 2012, pp. 126-127). 
20. Hermann Friedrich Graebe witnessed a similar event on 5 October 1943: "Without screaming or weeping these [Jewish] people undressed, stood around in family groups, kissed each other, said farewells and waited for a sign from another S.S.-man, who stood near the pit, also with a whip in his hand. During the 15 minutes that I stood near the pit I heard no complaint or plea for mercy" (quoted in Musmanno 1961, p. 105). See also Gitelman (1997, pp. 282-283), Johnson and Reuband (2005, pp. 239-240), and Kwiet (1998, p. 19).

21. Quoted in Hilberg (1961, p. 249). Hilberg emphasizes this issue: "The entire Jewish community, and particularly the Jewish leadership, now concentrated all its efforts in one direction - to make the ordeal bearable, to make death easy" (p. 668). However, as the Warsaw ghetto uprising and prisoner revolts at Treblinka, Sobibor, and Auschwitz (discussed later) show, Jewish resistance did increase.

22. Bauman (1989, p. 23). See also Goldhagen (1996, p. 219) and Kwiet (1998, p. 18).

23. Quoted in Benz (1999, p. 86).

24. Hilberg (1961, pp. 217-218).

25. Friedländer $(2007$, p. 362).

26. Arad et al. (1989, p. 228) and Headland (1992, p. 64).

27. Quoted in Headland (1992, p. 64).

28. Headland (1992, p. 64). Another example of the mentally ill's ironic resistance to Nazi persecution was noted by Primo Levi in his description of the indomitable concentration camp inmate Lindzin Elias who-ill-fit for normal society-seemed designed to survive the brutal deprivations of a place like Auschwitz, "Elias has survived the destruction from outside, because he is physically indestructible; he has resisted the annihilation from within because he is insane. So, in the first place, he is a survivor: he is the most adaptable, the human type most suited to this way of living. If Elias regains his liberty he will be confined to the fringes of human society, in a prison or a lunatic asylum" (2013, p. 109).

29. Longerich $(2012$, p. 536). Interestingly, there was a gap in Lange's gassing activities in the Wartheland between the start and end of October 1941 where his commando technically could have undertaken these killings in the Soviet interior (see Montague 2012, pp. 40-43).

30. Bauman (1989, p. 26).

31. Quoted in Musmanno (1961, p. 82).

32. Grossman (1995, p. 117).

33. Grossman (1995, p. 128).

34. For a similar example of shooters relying on this technique, see Cesarani (2016, p. 396). 
35. Angrick and Klein $(2009$, p. 134).

36. Browning (1992).

37. Kühl $(2016$, p. 77).

38. Kühl $(2016$, p. 87).

39. Somewhat similarly, one squad leader ensured that all his subordinates at least viewed (as spectators) an execution. This was to both "strengthen the group's sense of cohesiveness" and meant as a means of entrapment to ensure that nobody could later deny having a connection to, or knowledge of, the massacres (Angrick and Klein 2009, p. 140).

40. See Goldhagen (1996, p. 280).

41. Goldhagen (1996, p. 217). This shooting technique was relied on by some members of the SS during the Polish invasion (see Hochstadt 2004, pp. 90-91).

42. See Klee et al. (1988, p. 201).

43. Quoted in Wilhelm (1991, p. 231, as cited in Rhodes 2002, p. 114).

44. Langerbein $(2004$, p. 113).

45. As quoted in Pohl $(2008$, p. 29).

46. Pohl (2008, pp. 30-31).

47. Pohl (2008, p. 28). See also Bloxham and Kushner (2005, p. 136).

48. Pohl (2008, pp. 31-32).

49. Angrick and Klein (2009, p. 146).

50. Breitman (2000, p. 41).

51. Hilberg (1961, p. 196).

52. Büchler (1986, p. 17).

53. Browning (2004, pp. 326-327).

54. Browning $(1995$, p. 121).

55. Browning (2004, pp. 325-328).

56. Aly (2006, p. 117). Hitler's reversal in policy may also have been influenced by Stalin's forced resettlement of nearly half a million ethnic Germans living within the Soviet sphere of influence to Siberia (Cesarani 2016, p. 423).

57. Longerich $(2010$, p. 269$)$.

58. Aly (2006, p. 26).

59. Quoted in Aly (2006, p. 175).

60. Quoted in Aly (2006, p. 173).

61. Pohl (2008, p. 35).

62. Pohl (2008, p. 35).

63. Korey (1993, p. 62).

64. Pohl (2008, p. 35).

65. Quoted in Korey (1993, p. 63).

66. Quoted in Cesarani (2016, p. 404).

67. Quoted in Klee et al. (1988, p. 63). 
68. See Cesarani (2016, p. 367).

69. Quoted in Klee et al. (1988, pp. 64-66). See also Lozowick (1987, p. 224).

70. Angrick and Klein (2009, p. 134).

71. Korey (1993, p. 63).

72. Korey (1993, p. 63).

73. Quoted in Lozowick (1987, p. 236).

74. Quoted in Korey (1993, p. 62).

75. Lozowick (1987, p. 236).

76. Angrick and Klein (2009, p. 134).

77. Angrick and Klein (2009, p. 132).

78. Angrick and Klein (2009, p. 134).

79. Angrick and Klein (2009, pp. 135-136).

80. Angrick and Klein (2009, p. 136).

81. See Ritzer (2015, pp. 33-35).

82. Quoted in Gerth and Mills (1974, p. 214).

83. Pohl (1997, p. 405).

84. Quoted in Klee et al. (1988, p. 67).

85. Headland (1992, p. 211).

86. Höss (2001, pp. 147-148).

87. Quoted in Streit (1994, p. 116). See also Kwiet (1993, p. 88).

88. Lifton (1986, p. 15). See also Klee et al. (1988, pp. 83-84).

89. Quoted in Lower (2013, p. 93).

90. Pohl (2008, p. 42). Here Heydrich does not seem to have envisioned the extermination of the European Jews because around 13 October 1941 he approved of a proposal (revoked a few days later) to deport Spanish Jews based in France to Morocco (see Mommsen 1986, p. 123).

91. See Pohl (2008, p. 26).

92. Friedländer (2007, pp. 284-285).

93. Kühne $(2010$, p. 155).

94. Aly (2006, p. 127).

95. Head of the Cologne Finance Department (quoted in Aly 2006, p. 118).

96. Roseman (2002).

97. See, for example, Angrick and Klein (2009, p. 191).

98. Friedländer $(2007$, p. 339).

99. Quoted in Gerwarth (2011, p. 209).

100. Quoted in Friedländer (2007, p. 280).

101. Cesarani (2016, p. 416).

102. Hilberg (1980, p. 91).

103. Breitman (2000, p. 74$)$.

104. Angrick and Klein (2009, p. 130). 
105. Angrick and Klein $(2009$, p. 131).

106. Quoted in Angrick and Klein (2009, p. 134).

107. Angrick and Klein (2009, pp. 132-133).

108. Browning $(2004$, p. 395$)$.

109. Breitman (2000, pp. 82-83) and Angrick and Klein (2009, p. 146).

110. According to Jeckeln, on 10 and 11 November Himmler instructed him that it was "the Führer's wish" that the Jews in or destined for transition in the city of Riga were to undergo "evacuation to the East." Jeckeln confidently interpreted these ambiguous orders to mean, "the Riga ghetto was to be liquidated" (Fleming 1984, p. 44).

111. Breitman $(2000$, p. 83$)$ suspects Himmler wanted to save this particular transport because there were a number of decorated World War One veterans on board. Kershaw adds that Himmler perhaps received complaints that part-Jews and non-Jewish Germans with Jewish partners may have been among the deportees (2000, p. 122). Perhaps Himmler feared that if the German Jews were immediately shot, the Jews remaining in the west would soon hear about these massacres (as they did) and thereafter resist, as best they could, resettlement (see Cesarani 2016 , p. 430). Another possible reason these Jews were not to be shot was because a vacillating Hitler feared "a possible loss of prestige" (Mommsen 1986, p. 114).

112. Browning (2004, p. 398). See also Friedländer (2007, p. 267).

113. Browning $(2004$, p. 397).

114. Breitman (2000, p. 81) and Hilberg (2003, p. 304).

115. See Breitman (2000, pp. 83-84).

116. $\operatorname{Koonz}(2003$, p. 181).

117. Quoted in Longerich (2010, p. 298).

118. Quoted in Fleming (1984, p. 117). See also Browning (1992, p. 67).

119. Browning (2004, p. 397).

120. Angrick and Klein (2009, p. 152).

121. Angrick and Klein (2009, p. 152).

122. Pressac and van Pelt (1998, pp. 201, 208).

123. Gerlach (1997, p. 60).

124. Angrick and Klein (2009, p. 190). Interestingly, Himmler was in Mogilev between 23 and 25 October and discussed killing civilians with gas (Browning 2004, p. 189).

125. Gerlach (1997, pp. 65-69).

126. Angrick and Klein (2009, p. 190).

127. Quoted in Longerich (2010, pp. 279-280). During Wetzel's 1961 interrogation, he more specifically noted, "On 24 October 1941, I went to Brack's office in the Führer's Chancellery on Voßstrasse. Brack said...that he had an assignment for me. I was to convey the following 
message to Minister Rosenberg: Minister Rosenberg should inform Reichskommissar Lohse that he, Brack, had a gassing apparatus ready for shipment to Riga. Brack told me that the gassing apparatus was to be used on the Jews, and that Eichmann had agreed that this gassing van should be sent to Riga. Jewish convoys would also be sent to Riga and Minsk. [...] In the course of this briefing, Brack told me that this was a Führer-order or Führer-commission" (quoted in Fleming 1984, p. 110). See also Angrick and Klein (2006, p. 338, as cited in Longerich 2012 , p. 548).

128. Gerlach (1997, pp. 60, 67, 69).

129. Breitman $(2000$, p. 85$)$.

130. Matthäus $(2004$, p. 273).

131. Breitman (2000, p. 52) and Matthäus (2007, p. 231).

132. Quoted in Browning (2004, p. 310).

133. Breitman $(2000$, p. 53$)$.

134. Browning (1994, p. 140).

135. Browning (1995, p. 106).

136. According to one report by Einsatzgruppe D, "The Romanians proceed against the Jews without any plans. There would be nothing to complain about the very numerous shootings of Jews if the technical preparations and implementation were not so inadequate" (quoted in Browning 2004, p. 400). Dicks (1972) tells how the prosecutor at one SS officer's trial suggested the officer had “stopped the wild shooting of the Lithuanian auxiliary police, but he substituted for it the routine mechanical slaughter of the Chicago stockyards at the rate of 500 [Jews] a day" (p. 206).

137. Quoted in Klee et al. (1988, p. 153).

138. Quoted in Klee et al. (1988, p. 154).

139. See, for example, Matthäus (2004, p. 275$).$

140. Quoted in Klee et al. (1988, p. 81).

141. Quoted in Klee et al. (1988, p. 46).

142. Matthäus (2004, p. 273).

143. MacQueen (1997, p. 100).

144. Angrick and Klein (2009, p. 156).

145. Quoted in Klee et al. (1988, p. 126). See also Hilberg (1992, pp. 63-64, 95-96).

146. Lower (2005, pp. 251-252).

147. In Belorussia, where locals were not particularly interested in collaborating in the extermination process, the Germans frequently imported shooters from Latvia and Lithuania (Matthäus 2004, p. 268). The Germans were so reliant on Latvian executioners to do their dirty work 
that Schneider (1993, p. 193) terms these shooters Latvia's "most famous 'export'."

148. Quoted in Schneider (1993, p. 183).

149. Arad (1987, pp. 20-21) and Browning (1992, p. 52).

150. Quoted in Herbert (2000, p. 257, as cited in Rees 2005, p. 44).

151. Breitman (1991, p. 204).

152. Hilberg (1961, p. 646).

153. Lower $(2005$, p. 251$)$.

154. Allen (2005, p. 266).

155. Quoted in Lower (2002, p. 14).

156. Jeckeln was probably an exception. In all likelihood, he was driven more by a competitive desire to most impressively implement the "Führer's wish" than by a concern to ease his men's psychological burden (see Angrick and Klein 2009, p. 146). Jeckeln certainly saw Stahlecker's Einsatzgruppe A (more specifically Jäger's small yet highly lethal commando) as his main competition (p. 135). When Jäger liquidated a trainload of Reich Jews in Kaunas on 25 November, Jeckeln chose to disobey Himmler's orders to house (and not shoot) the first trainload of Reich Jews sent his way.

157. Karl Kretschmer of Sonderkommando 4a (quoted in Klee et al. 1988, p. 171).

158. Kühl (2016, pp. 143-147).

159. Bauman $(1989$, p. 15). Bauman, however, has most frequently been criticized because he focuses too much on the clearly modern factory-like model of Auschwitz and pays little attention to the (apparently) disorganized, emotionally proximate, and unbureaucratic mass shootings (see Bloxham 2008, p. 209; De Swaan 2015, p. 255; Kühl 2016, pp. 22-23; Lawson 2010, p. 148). As Bloxham and Kushner (2005, p. 155) put it: "Neither can the murder by shooting in situ of millions of Polish, Soviet and Serbian Jews be described in any meaningful sense as a modern 'bureaucratic' process." This chapter, however, challenges Pohl's (1997, p. 405) "de-bureaucratization" thesis (as Bloxham and Kushner describe it).

160. Seehttp://www.ushmm.org/wlc/en/article.php?ModuleId=10005219. Accessed 14 September 2017.

161. Lower (2005, p. 245). 


\section{REFERENCES}

Allen, M. T. (2005). Introduction: A bureaucratic Holocaust-Toward a new consensus. In G. D. Feldman \& W. Seibel (Eds.), Networks of Nazi persecution: Bureaucracy, business, and the organization of the Holocaust (pp. 259268). New York: Berghahn Books.

Aly, G. (2006). Hitler's beneficiaries: Plunder, racial war, and the Nazi welfare state. New York: Metropolitan Books, Henry Holt and Company.

Angrick, A., \& Klein, P. (2009). The "final solution" in Riga: Exploitation and annibilation, 1941-1944. New York: Berghahn Books.

Arad, Y. (1987). Belzec, Sobibor, Treblinka: The Operation Reinhard death camps. Bloomington: Indiana University Press.

Arad, Y., Krakowski, S., \& Spector, S. (1989). The Einsatzgruppen reports: Selections from the dispatches of the Nazi death squads' campaign against the Jews in occupied territories of the Soviet Union July 1941-January 1943. New York: Holocaust Library.

Bauman, Z. (1989). Modernity and the Holocaust. Ithaca, NY: Cornell University Press.

Baumeister, R. F. (1997). Evil: Inside human cruelty and violence. New York: W. H. Freeman.

Benz, W. (1999). The Holocaust: A German historian examines the genocide. New York: Columbia University Press.

Bloxham, D. (2008). Organized mass murder: Structure, participation, and motivation in comparative perspective. Holocaust and Genocide Studies, 22(2), 203-245.

Bloxham, D., \& Kushner, T. (2005). The Holocaust: Critical historical approaches. Manchester, UK: Manchester University Press.

Breitman, R. (1991). The architect of genocide: Himmler and the final solution. New York: Alfred A. Knopf.

Breitman, R. (2000). Official secrets: What the Nazis planned, what the British and Americans knew. London: Penguin Books.

Browning, C. R. (1992). Ordinary men: Reserve Police Battalion 101 and the final solution in Poland. New York: HarperCollins.

Browning, C. R. (1994). Hitler and the euphoria of victory: The path to the final solution. In D. Cesarani (Ed.), The final solution: Origins and implementation (pp. 137-147). New York: Routledge.

Browning, C. R. (1995). The path to genocide: Essays on launching the final solution. New York: Cambridge University Press.

Browning, C. R. (2004). The origins of the final solution: The evolution of Nazi Jewish policy, September 1939-March 1942. Lincoln: University of Nebraska Press.

Büchler, Y. (1986). Kommandostab Reichsführer-SS: Himmler's personal murder brigades in 1941. Holocaust and Genocide Studies, 1(1), 11-25. 
Cesarani, D. (2016). Final solution: The fate of the Jews 1933-1949. London: Macmillan.

De Swaan, A. (2015). The killing compartments: The mentality of mass murder. New Haven, CT: Yale University Press.

Desbois, F. P. (2008). The Holocaust by bullets: A priest's journey to uncover the truth behind the murder of 1.5 million Jews. New York: Palgrave Macmillan.

Dicks, H. V. (1972). Licensed mass murder: A socio-psychological study of some SS killers. London: Heinemman Educational for Sussex University.

Fleming, G. (1984). Hitler and the final solution. Berkeley, CA: University of California Press.

Friedländer, S. (2007). The years of extermination: Nazi Germany and the Jews, 1939-1945. New York: Harper Perennial.

Gerlach, C. (1997). Failure of plans for an SS extermination camp in Mogilëv, Belorussia. Holocaust and Genocide Studies, 11(1), 60-78.

Gerth, H. H., \& Mills, C. W. (1974). From Max Weber: Essays in sociology. New York: Oxford University Press.

Gerwarth, R. (2011). Hitler's hangman: The life of Heydrich. New Haven, CT: Yale University Press.

Gitelman, Z. (1997). Eyewitness accounts. In Z. Gitelman (Ed.), Bitter legacy: Confronting the Holocaust in the USSR (pp. 275-285). Bloomington: Indiana University Press.

Goldhagen, D. J. (1996). Hitler's willing executioners: Ordinary Germans and the Holocaust. London: Alfred A. Knopf.

Grossman, D. (1995). On killing: The psychological cost of learning to kill in war and society. Boston: Little Brown.

Headland, R. (1992). Messages of murder: A study of the reports of the Einsatzgruppen of the security police and the security service, 1941-1943. London: Associated University Press.

Hilberg, R. (1961). The destruction of the European Jews. Chicago: Quadrangle Books.

Hilberg, R. (1980). The anatomy of the Holocaust. In H. Friedlander \& S. Milton (Eds.), The Holocaust: Ideology, bureaucracy, and genocide (The San José papers) (pp. 85-94). Millwood, NY: Kraus International Publications.

Hilberg, R. (1992). Perpetrators, victims, bystanders: The Jewish catastrophe, 1933-1945. New York: HarperCollins.

Hilberg, R. (2003). The destruction of the European Jews (3rd ed., Vols. 1-3). London: Yale University Press.

Hochstadt, S. (2004). Sources of the Holocaust. New York: Palgrave Macmillan.

Höss, R. (2001). Commandant of Auschwitz: The autobiography of Rudolf Hoess. London: Phoenix Press.

Johnson, E. A., \& Reuband, K. H. (2005). What we knew: Terror, mass murder and everyday life in Nazi Germany, an oral history. London: John Murray. 
Kershaw, I. (2000). The Nazi dictatorship: Problems and perspectives of interpretation (2nd ed.). London: Arnold.

Klee, E., Dressen, W., \& Riess, V. (Eds.). (1988). "The good old days": The Holocaust as seen by its perpetrators and bystanders. New York: Free Press.

Koonz, C. (2003). The Nazi conscience. London: The Belknap Press of Harvard University Press.

Korey, W. (1993). A monument over Babi Yar. In L. Dobroszycki \& J. S. Gurock (Eds.), The Holocaust in the Soviet Union: Studies and sources on the destruction of the Jews in the Nazi-occupied territories of the USSR, 1941-1945 (pp. 61-74). Armonk, NY: M.E. Sharpe.

Kühl, S. (2016). Ordinary organizations: Why normal men carried out the Holocaust. Cambridge, UK: Polity Press.

Kühne, T. (2010). Belonging and genocide. New Haven: Yale University Press.

Kwiet, K. (1993). From the diary of a killing unit. In J. Milfull (Ed.), Why Germany? National socialist anti-semitism and the European context (pp. 73-90). Oxford, UK: Berg.

Kwiet, K. (1998). Rehearsing for murder: The beginning of the final solution in Lithuania in June 1941. Holocaust and Genocide Studies, 12(1), 3-26.

Langerbein, H. (2004). Hitler's death squads: The logic of mass murder. College Station: Texas A\&M University Press.

Lawson, T. (2010). Debates on the Holocaust. Manchester: Manchester University Press.

Levi, P. (2013). If this is a man and the truce. London: Abacus.

Lifton, R. J. (1986). The Nazi doctors: Medical killing and the psychology of genocide. New York: Basic Books.

Longerich, P. (2010). Holocaust: The Nazi persecution and murder of the Jews. Oxford, UK: Oxford University Press.

Longerich, P. (2012). Heinrich Himmler. Oxford, UK: Oxford University Press.

Lower, W. (2002). "Anticipatory obedience" and the Nazi implementation of the Holocaust in the Ukraine: A case study of the central and peripheral forces in the Generalbezirk Zhytomyr, 1941-1944. Holocaust and Genocide Studies, $16(1), 1-22$.

Lower, W. (2005). The "Reibungslose" Holocaust? The German military and civilian implementation of the "final solution" in Ukraine, 1941-1944. In G. D. Feldman \& W. Seibel (Eds.), Networks of Nazi persecution: Bureaucracy, business, and the organization of the Holocaust (pp. 236-256). New York: Berghahn Books.

Lower, W. (2013). Hitler's furies: German women in the Nazi killing fields. New York: Houghton Mifflin Harcourt.

Lozowick, Y. (1987). Rollbahn mord: The early activities of Einsatzgruppe C. Holocaust and Genocide Studies, 2(2), 221-241. 
MacQueen, M. (1997). Nazi policy towards the Jews in Reichskommissariat Ostland, June-December 1941: From white terror to Holocaust in Lithuania. In Z. Gitelman (Ed.), Bitter legacy: Confronting the Holocaust in the USSR (pp. 91-103). Indianapolis: Indiana University Press.

Markusen, E., \& Kopf, D. (1995). The Holocaust and strategic bombing: Genocide and total war in the twentieth century. Boulder, CO: Westview Press.

Matthäus, J. (2004). Operation Barbarossa and the onset of the Holocaust, June-December 1941. In C. R. Browning (Ed.), The origins of the final solution: The evolution of Nazi Jewish policy, September 1939-March 1942 (pp. 248-308). Lincoln: University of Nebraska Press.

Matthäus, J. (2007). Controlled escalation: Himmler's men in the summer of 1941 and the Holocaust in the occupied Soviet territories. Holocaust and Genocide Studies, 21(2), 218-242.

Mommsen, H. (1986). The realization of the unthinkable: The 'final solution of the Jewish question' in the Third Reich. In G. Hirschfeld (Ed.), The policies of genocide: Jews and Soviet prisoners of war in Nazi Germany (pp. 97-144). London: Allan \& Unwin.

Montague, P. (2012). Chetmno and the Holocaust: The history of Hitler's first death camp. London: I.B. Tauris.

Musmanno, M. A. (1961). The Eichmann Kommandos. London: Peter Davies.

Naumann, B. (1966). Auschwitz. New York: Praeger.

Neitzel, S., \& Welzer, H. (2012). Soldiers: On fighting, killing and dying: The secret Second World War transcripts of German POWs. New York: Alfred A. Knopf.

Pohl, D. (1997). Nationalsozialistische Judenverfolgung in Ostgalizien 19411944: Organisation und Durchfübrung eines staatlichen Massenverbrechens. Munich: Oldenbourg.

Pohl, D. (2008). The murder of Ukraine's Jews under German military administration and in the Reich Commissariat Ukraine. In R. Brandon \& W. Lower (Eds.), The Shoah in Ukraine: History, testimony, memorialization (pp. 23-76). Bloomington: Indiana University Press.

Pressac, J. C., \& van Pelt, R. J. (1998). The machinery of mass murder at Auschwitz. In Y. Gutman \& M. Berenbaum (Eds.), Anatomy of the Auschwitz death camp (pp. 183-245). Bloomington: Indiana University Press.

Rees, L. (2005). Auschwitz: A new history. New York: BBC Books.

Rhodes, R. (2002). Masters of death: The SS-Einsatzgruppen and the invention of the Holocaust. New York: Alfred A. Knopf.

Ritzer, G. (2015). The McDonalization of society (8th ed.). Los Angeles, CA: Sage.

Roseman, M. (2002). The villa, the lake, the meeting: Wannsee and the final solution. London: Penguin Press. 
Schneider, G. (1993). The two ghettos in Riga, Latvia, 1941-1943. In L. Dobroszycki \& J. S. Gurock (Eds.), The Holocaust in the Soviet Union: Studies and sources on the destruction of the Jews in the Nazi-occupied territories of the USSR, 1941-1945 (pp. 181-193). Armonk, NY: M.E. Sharpe.

Streit, C. (1994). Wehrmacht, Einsatzgruppen, Soviet POWs and anti-Bolshevism in the emergence of the final solution. In D. Cesarani (Ed.), The final solution: Origins and implementation (pp. 103-118). New York: Routledge.

Open Access This chapter is licensed under the terms of the Creative Commons Attribution 4.0 International License (http://creativecommons.org/licenses/ by $/ 4.0 /$ ), which permits use, sharing, adaptation, distribution and reproduction in any medium or format, as long as you give appropriate credit to the original author(s) and the source, provide a link to the Creative Commons licence and indicate if changes were made.

The images or other third party material in this chapter are included in the chapter's Creative Commons licence, unless indicated otherwise in a credit line to the material. If material is not included in the chapter's Creative Commons licence and your intended use is not permitted by statutory regulation or exceeds the permitted use, you will need to obtain permission directly from the copyright holder.

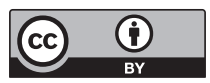

